\title{
The Impact of Human Resource Management Practices and the Implementation of Quality Management Systems on Business Performance: An Empirical Study of Sri Lankan Manufacturing Firms - A Conceptual Model
}

\author{
Lalith Nimal Senaweera ${ }^{1}$ and K. A. S. Dhammika ${ }^{2}$ \\ ${ }^{1}$ Retired Director General/CEO- Sri Lanka Standards Institution \\ ${ }^{2}$ Department of Human Resource Management, Faculty of Commerce and \\ Management Studies, University of Kelaniya, Sri Lanka \\ ${ }^{1}$ senaweera12@gmail.com, ${ }^{2}$ kasdhammika@yahoo.com \\ (D) https://orcid.org/0000-0002-3998-8066
}

\begin{abstract}
This study proposed a framework for the moderating effect of Firm Size and the Firm Age (Years of implementation of Quality Management Practices) on the Impact of Human Resource Management (HRM) Practices and the Implementation of Quality Management System (QMS) on business performance of manufacturing firms in Sri Lanka. However, the extensive Literature review revealed that relatively few studies have attempted to consider the relationship between Total Quality Management (TQM) and business performance, ISO 9000 certified companies and business performance, and HRM practices and business performance by researchers in different countries including Sri Lanka in the different context.
\end{abstract}

The majority of the studies conducted on the relationships between the constructs have presented different findings. Moreover, no studies have been conducted to determine the moderating effect of the variables like Firm Size and Firm Age (Years of implementation of Quality Management System) on the relationship of HRM practices and business performance in manufacturing firms and also the moderating effect of the same variables on the relationship between the Implementation of Quality Management Systems (QMS) and business performance in manufacturing firms. In order to bridge the gap in the literature, this study proposes a conceptual model identifying two moderating variables Firm Size and Firm Age (years of Implementation of QMS) based on the extensive review of the literature. Hence, a research framework has been propounded to ascertain the relationships between the constructs in a future study.

This conceptual model is significant to policy makers, government, regulators, and financial Institutions on the need to provide information on moderating effect of variables to the real and potential entrepreneurs for manufacturing firms' development in Sri Lanka. In addition, the conceptual model will serve as additional 
literature on the business performance of manufacturing firms in emerging economies like Sri Lanka that has not been explored.

Keywords: Business Performance, Human Resource Management Practices, ISO 9000, Manufacturing Firms, Quality Management Systems (QMS), and Total Quality Management (TQM)

\section{Introduction}

The business environment has become very competitive and challenging with the globalization of trade activities and hence the manufacturing firms have to make changes to meet the new requirements in the business world. In this context, Schuler and Jackson (2005), indicate that in the competitive and unstable markets, Human Resource Management practices (HRMP) can be used as a source to generate novel ideas to turn the organizations to achieve competitive advantage. Similarly, Nzuve (2007) indicates that use of good Human Resource Management practices (HRMPs) is very much important to achieve organization goals and to enhance employee productivity. Moreover, Pfeffer (2005); Walker (2001) found that HRMPs support to gain competitive advantage. Furthermore, Sang (2005) that HRMPs are positively related to the organizational performance.

Human Resources Management plays a vital role in today's global markets. According to Pfeffer (1994); Barney and Wright (1998), organizations that are competitive in global markets maintain the position to gain the competitive advantage because of managing organization specific human resources and system.

According to, the Global Competitiveness Report 2016/2017 published by the Geneva- Based World Economic Forum, Sri Lanka $71^{\text {st }}$ among 138 countries in the index of global competitiveness with a score of 4.19 out of 7. This indicates that the manufacturing sector needs to play a higher role in order to meet the challenges taking place in the global environment. According to Zutshi and Sohal( 2005), certification based on ISO 9000 Quality management System is well recognized within the developed countries and across the globe as it can be applicable to any firm. Klefsjo, Bergquist, and Edgerman (2006) indicated in global level manufacturing firms are pressurized to meet the unprecedented changes taking place by delivering quality products and services paving the way to comply with ISO 
certification to improve performance. Similarly, Quazi, Hong, and Meng (2002) indicated that pressures are also coming from governments to manufacturing firms to produce quality products to meet the needs and wants of consumers.

According to Ismyrlis and Moschidis (2015), firms to be competitive in the changing business environment, quality practices have to be considered as the strategic weapon to meet the ever changing technological developments and customer requirements. Fassoula (2006) indicates that manufacturing firms need to consider the successfully implemented quality practices in anywhere in the world so that practices need to be adopted in order that the firms can understand the gaps to initiate actions in a proactive manner to improve the performance continuously.

\section{Significance of the Study}

This research will contribute significantly to promote and facilitate the use of Human Resource practices coupled with the implementation of Quality Management practices in the manufacturing firms in Sri Lanka as the study intends to determine the influence of such practices on business performance of said firms. Moreover, with the intense competition taking place in the manufacturing business environment due to globalization most of the manufacturing firms in Sri Lanka implement Quality Management practices to enhance the business performance. But at present no studies are carried out in the Sri Lankan context to ascertain whether such practices when coupled with human resource practices would really provide the expected results of business performance. Therefore this initiative will cover the latest research gap on the Human Resource Management and the implementation of Quality Management practices as well as gaining sustainability in the literature. Hence, this study is immensely significant for manufacturing firms in Sri Lanka by offering new insights into the practices of Human Resource and Quality Management that could support to improve the business performance of manufacturing firms in Sri Lanka. Furthermore, theoretical contribution of this study is significant because the research model will form theoretical and practical variables to relate, HRM practices and Quality Management practices on business performance.Moreover, the findings of this study will be useful to government and other organizations in Sri Lankathat are 
practicing Human resource and Quality management as well as those seeking to establish those practiceswithin the systems with the aim of improving performance.The study also offers significant values for practitioners since it has considerable managerial significance.

\section{Objectives of the Study}

The current study aims to achieve the following objectives.

i. To investigate the relationship between HRM practices and Business Performance of Sri Lankan manufacturing firms

ii. To determine the relationship between Quality Management Systems practices and Business Performance of Sri Lankan manufacturing firms

iii. To identify the moderate effect of firm size and firm age on the relationship between HRM practices and Business Performance of Sri Lankan manufacturing firms

iv. To identify the moderate effect of firm size and firm age on the relationship between Quality Management System practices and Business Performance of Sri Lankan manufacturing firms

v. To propose a suitable Quality System structure coupled with the HRM practices to improve Business Performance of Sri Lankan manufacturing firms

\section{Problem Statement}

Although the factors that contribute to the business performance of manufacturing firms are various and complex, but the Human Resource Management (HRM) practices and the Business Performance (BP) and the Implementation of Quality Management Systems (QMS) and the Business Performance have been widely recognized in the literature as among the important determinants of good business performance. Therefore, the relationship between HRM practices and the implementation of the QMS and $\mathrm{BP}$ with the moderator effect on the relationship from firm size and firm age of manufacturing firms provide an interesting phenomenon for scientific research. Although the amount of study on the relationship between HRM practices and BP and QMS practices and BP that reported in the literature are encouraging, but the issue of the interrelationship between HRM and the 
implementation of QMS and BP with moderator effect from firm size and firm age were not fully explored.

\section{Research Questions}

Given to the shortcomings in the literature this study undertakes to explore:

i. To what extent HRM practices and the Implementation of QMS are related to gain good financial performance in the manufacturing firms of Sri Lanka?

ii. Is there a moderator effect on the relationship between HRM practices and BP from firm age and firm size?

iii. Is there a moderator effect on the relationship between QMS and BP from firm age and firm size?

\section{Methodology}

This is primarily a conceptual paper focusing on the methodology of conducting systematic reviews of research and this paper uses Tranfield et al., (2003) archival method for reviewing literature that helps researcher to determine the relevant literature and to structure the literature to make reliable measuring dimensions. Moreover, the paper draws on a database of reviews of research previously conducted in human resource management and quality management systems covering books, journal articles, and other research papers over the past decades. In a separate effort, the author categorizes the identified relevant literature to understand and to illustrate broader trends with respect to how the various key elements of the framework have been employed in exemplary reviews. The paper draws upon key dimensions for measuring based on the in-depth review of collected relevant publications as a means of clarifying and elaborating on the elements of the conceptual framework.

\section{Review of Literature}

\subsection{Human Resource Management and Business Performance}

The Literature revealed extensive studies have been conducted by researchers in the US and UK in the area of HRM and organizational performance. In view of that, Ericksen and Dyer (2005); Wright, Filatotchev, Hoskisson, and 
Peng (2005) emphasized the necessity of doing such research work in other countries.

HRM practices and to determine its impact on organization had been increased as many scholars conducted research in this area. For example, many studies conducted to determine the influence of HRM on organizational performance in large companies (Guthrie \& Hollensbe, 2004; Hayton, 2003; Becker \& Gerhart, 1996; Huselid, 1995; Arthur, 1994; Wright \& McMahan, 1992). Moreover, research findings in the manufacturing sector proved that there was a relationship between HRM practices and firm performance (Arthur, 1994; MacDuffie, 1995; Ichniowski, Shaw, \& Prennushi, 1997) and with respect to service sector the same association was proved by (Batt, 2002).

According to (Khan, 2010), with the development of the HRM subject many researchers' tend to conduct research on overall HRM System and its influence on organization performance rather than conducting research on determining the association of particular elements of HRM practices on business performance. Moreover, Teseema and Soeters (2006); Wall and Wood (2005) found that many studies were conducted to determine the relationship between the HRM practices and performance only by considering single HRM functions.

However, a study on HRM practices and firms performance concluded that there was a sound linked between HRM practices and organizational performance and the relationship with the market performance (Uysal \& Koca, 2009). Furthermore, according to (Khan, 2010), the relationship between HRM practices and organizational performance, the results revealed that the relationship was a significant positive one. For this study Khan (2010) used the HRM functions like recruitment and selection, training and development, performance appraisals and compensation to determine the link between organizational performances and found that all were having a significant positive relationship with the organizational performance. Moreover, Sels et al., (2006); Way (2002) concluded that HRM and Organizational performance are related positively in SMEs. Active involvement of human resource system and human resource practices. Furthermore, Pfeffer (1994, 1988); Mudrack (1993); Judge, Scott, and Ilies (2006); Okpara and Pamela (2008) hypothesized on the improvement of 
business performance through high involvement of human resource system and human resource practices.

\subsection{Quality Management Systems Implementation and Business Performance}

An extensive review of the literature provides that a great deal of empirical research investigates the relationship between TQM and performance. However, the results were mixed as some authors proved positive results (EIShenaway, Baker, \& Lemak, 2007), other Scholars failed to prove any significant link (Powell, 1995; Westphal, Gulati, \& Shortell, 1996), and other studies even identify an inverse relationship (Davis, 1997). Moreover, another argument was that the QMS standard based on quality management practices is a necessary foundation for other quality methods under TQM (Taylor, 1997) leading to enhanced performance.

According to Power and Sohal (2000), total quality management (TQM) is an organization-wide process-oriented philosophy that requires changes not only in production systems, but also in decision-making processes, employee development, and employee participation and involvement. Moreover, Fotopoulos and Psomas (2009); Gadenne and Sharma (2009); Tari(2007); Rahman and Bullock (2005); Ahire et al., (1996); Louise (1996); Powell (1995); Flynn et al., (1995) provide evidence for the relationship between total quality management and organizational performance. According to Gadenne and Sharma (2009), Organization performance connected with the hard factors namely, benchmarking and quality measurement, continuous improvement, and efficiency improvement and also with the soft factors such as top management philosophy and supplier support, employee training and increased interaction with employees and customer.

ISO 9000 is a quality management system standard which was published in 1987 by the International Organization for Standardization (ISO), which is the world's largest non-profit organization. ISO 9000 family of standards provides a platform for organizations to design, implement, and establish sound quality management systems.

Furthermore, Feng et al., (2007) concluded a positive and significant relationship between ISO 9000 certification and business performance. Similarly, Heras, Dick, and Casadesds (2002) concludes that ISO 9000 
implementation has a positive impact on sales and profitability. Moreover, another study, Lafuente, Bayo-Moriones, Garcia- Cestona (2010) supported the view that ISO-9000 certification positively impacts firm performance. Similarly, Wambugu (2010) argued that ISO 9001: 2008 ensures that customers get consistent, good quality products and services, which also brings many business benefits such as better performance in the manufacturing industries.However, Sun (2000); Withers and Ebrahimpour (2000) found that the positive results are shown through the studies of improvements based on defects reduction.

Sun (2000) and Chow-Chua (2003) concluded that ISO 9000 certification has no positive impact on the improvement of business performance. Similarly, White (1999) proved that ISO 9000 has no impact on operational performance and foreign sales. Moreover, the relation with ISO 9000 certification and business performance still remain unanswered in the literature (Anyango \& Wanjau, 2011). However, no conclusion was made about the relationship between the impacts of ISO 9000 certification on operational performance (Terziovski, Samson, \& Dow, 1997).

\subsection{Business Performance}

Although there is no clear performance definition in the literature, there is a general agreement that it should not be limited just to the financial results (Quinn \& Rohrbaugh, 1983; Venkatraman \& Ramanujam, 1986) since it would be a partial vision of the business situation (Curkovic, Vickery, \& Dröge , 2000).Firm performance can be measured in various ways. These may include but not limited to sales growth rate, market share, productivity and profitability (Ichniowski, Shaw, \& Prennushi, 1997). Sales growth rate is a ratio that measures the rate of change in sales from time to time or a specified period of time. However, Sila and Ebrahimpour (2005) indicate that business results can be measured using factors like Customer focus result, Human resource results, Financial and market results, and Organizational effective result.

\section{Proposed Conceptual Framework and the Hypotheses}

A search through the academic literature reveals insufficient evidence of the Impact of HRM practices and the implementation of Quality Management System on business performance in manufacturing firms in Sri Lanka. 
Moreover, no evidence found in the literature about the moderating effect of firm size and firm age on business performance based on HRM practices and Quality Management System. The manufacturing firms in Sri Lanka have pursued a number of Quality Management Systems (QMS), such as Total Quality Management (TQM), Just-in-Time (JIT) concept, the Sri Lanka National Quality Award (SLNQA) and ISO 9000 to improve performance. Nevertheless, ISO 9000 is the most popular quality concept whereas TQM and SLNQA are not to that level popular within the manufacturing firms of Sri Lanka. However, so far no studies have been conducted to determine the Impact of HRMPs and the implementation of Quality Management System (QMS) on business performance in the manufacturing firms of Sri Lanka.

This continues to be a matter of concern for researcher and in view of that the researcher for this study is developed and proposed a conceptual framework for future study to determine the relationships between the constructs. Based on that, the following arguments and hypotheses are proposed. Using those hypotheses, the researcher developed the conceptual model given as figure 1 to be used for a future study in the manufacturing firms of Sri Lanka.

The conceptual framework of this study includes two main independent variables and one dependent variable. Independent variables are the ones that influence or affect outcomes. Moreover, Independent variables are identified as manipulated, antecedent, or predictor variables whilst dependent variables are factors that depend on the independent variables or outcomes or results of the independent variables. Other names for dependent variables are criterion, outcome, and effect variables (Cresswell, 2007). Furthermore, two moderating variables are considered to determine the effect of such variables on the relationship between the two independent variables and the dependent variable. The links between Human Resource Management Practices and the Implementation of Quality Management Systems are incorporated into one single model.

In these ten hypotheses, Human Resource Management practices is an independent variable and the factors such as Recruitment \& Selection, Training and development, Performance Management, Compensation and Rewards and Employee Involvement are used to measure HRMP and the Quality Management Systems (QMS) implementation is the other independent variable and the factors such as Top Management Commitment, 
Customer Focus, Process Management, Supplier Quality Management and Continual Improvement are used to measure QMS implementation. The dependent variable is business performance. There are two moderator variables namely Firm Size and Firm Age which are used to measure the moderating effect of the relationships between independent and dependent variables. 


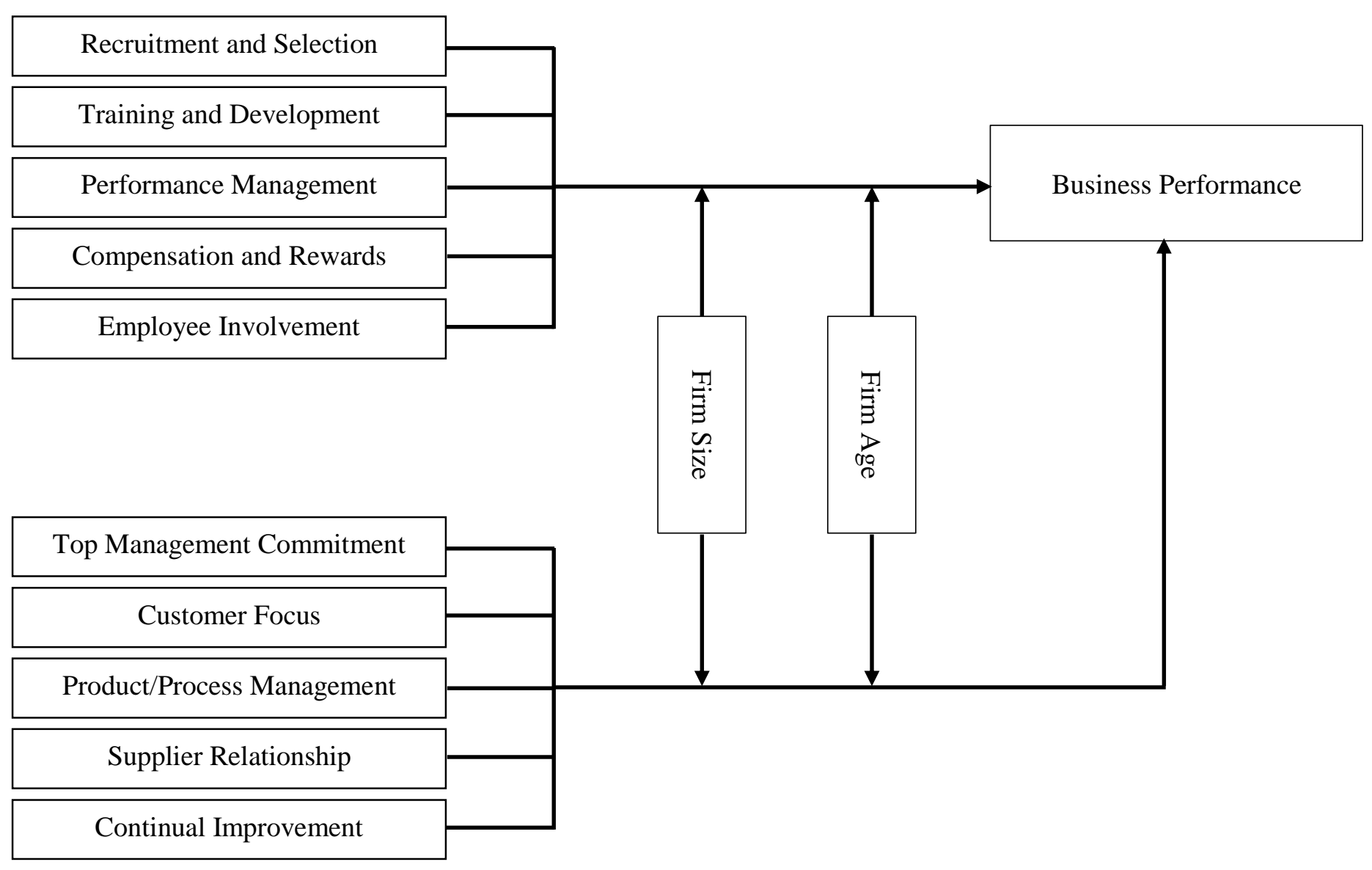




\section{Theories Underpinned the Conceptual Model}

The Conceptual model is underpinned with the theories such as Human Capital Theory, Resource Based View Theory and Equity Theory, Quality Improvement Theory and models. According to Teixeira (2002), people are like fixed capitals as like machines because people capabilities have cost and that generate profits. Moreover, Armstrong (2006) indicates that the basis of the human capital theory is that when people use the skills, abilities, and experience in a collective manner for the betterment of the organization that is a significant contribution to the success of the organization and to gain competitive advantage.

Fotopoulos, Kafetzopoulos, and Psomas (2009) mentioned that the ResourceBased View (REV) theory suggests that a firm's performance depends on its unique resources and capabilities. Similarly, Barney (1991) suggests that The Resource-Based View (RBV) theory proposes that to maintain a sustainable competitive advantage one of the vital factors that firms need to ensure is to have a human resource pool that cannot be matched by the competitors. In other words, the Resource-Based view, suggests that the workforce of the firms need to be evaluated repeatedly so as to determine whether the right people with the right skills in the right places so as to maintain sustained competitive advantage. Moreover, if this process is not taking place firms should use and an appropriate recruitment and selection criteria to fill the vacancies (Barney, 2001). Furthermore, the theory also provides that the human resource pool of the firm determines the strengths and weakness of the firm and the quality of employees working relationships. According to Boxall (1998), to develop a human capital advantage the firms need to recruit and retain talented individuals. On the other hand, firms can purchase technology and capital at any time for a price, but to have a human resource pool of qualified and motivated employees is so difficult (Sparrow et al., 2002). Thus, in order to maintain the uniqueness, the firms need to be very careful with the recruitment and selection process.

Equity Theory as proposed by Adams (1963) emphasizes the fact of fairness. Adams Equity Theory is not just evaluation of effort and reward. Moreover, Equity Theory supports a critical perspective of comparison with people that can consider in the same situation. However, many researchers Kuntze and Matulich (2010); Oyer (2004); Rajan and Wulf (2006); Rosen (2000a) 
consider that legitimate incentives support to increase productivity.

The Quality Improvement Theory of Deming (1986) hypothesizes that the weight age given for responsibility of the top management is the most important fact in the Quality management concept of manufacturing firms. The theory states that the management is responsible for the systems and that it is the system that generates 80percent of the problems in firms (Hill, 1995).

Deming (1986) noted that no quality management system could succeed without top management commitment; it is the management that invests in the processes, creates the corporate culture and also selects suppliers and develops long-term relationships. According to Anderson et al., (1994), the Quality Improvement provides the needs to mainly target on the quality issues when developing an organization system which provides a platform for cooperation and learning paving the way to implementing process management practices leading to performance. Juran (1998) developed Quality trilogy - quality planning, quality control and quality management. Juran (1998) believed that the main quality problems point to the management rather than to the workers and that quality can be attained only by making the functions and activities efficient and effective. Crosby (1979) defines for a sound quality improvement program, the practices such as management participation, management responsibility for quality, employee recognition, education, reduction of the cost of quality, emphasis on prevention rather than, after- the- event inspection, doing things right the first time, and zero defects are included.

\section{Hypotheses}

\subsection{Recruitment \& Selection}

Elwood and James (1996) indicate that resource requirements of organizations are done through proper recruitment and selection which in turn support the organization prospers and existence on short to medium -term. According to Gamage (2014), existing evidence indicates that recruitment and selection and the performance are having a significant positive relationship. Moreover, Ichniowski and Shaw (1999); Katou and Budhwar (2006); Wright et al., (2005) proved that recruitment and selection and performance are positively related. Thus the following hypothesis was proposed. Hence: 
$\mathbf{H}_{1}$ : $\quad$ Recruitment and Selection are positively correlated with business performance.

\subsection{Training and Development}

Manente (2008) indicated that the development of staff through the enhancement of knowledge helps to create a sound human resource which leads to achieve the organizational goals. Colarelli and Montei (1996); Becker (1993) concluded that based on the researched done effective training programs contribute to higher return on investments whilst other research findings proved that training contributes to higher retention of employees. According to Antonacopoulou (2000), capacity building of employees is considered as the employee development and which in turn contribute to meet the accepted performance levels of the whole organization. Similarly, Champathes (2006) indicated that higher the development of employees higher the job satisfaction of such employees and that leads to a higher productivity and profitability of the firm. Therefore, the following hypothesis was proposed:

$\mathrm{H}_{2}$ : $\quad$ Training and Development are positively correlated with business performance.

\subsection{Performance Management}

According to Bititci, Carrie, and McDevitt (1997), performance management is a process that manages the organization performance by aligning the corporate and functional strategies and objectives. Moreover, Sharma and Gadenne (2002); Madu, Aheto, Kuei, and Winokur (1996) indicate that organizational performance improvement requires measurements to determine the extent of the use of organizational resources that impact on business performance. Similarly, Nayab (2011) indicates that the dynamic changes taking place in the external environment and challenging nature of the economy have made organizations focus on proactive performance management from reactive performance appraisal to increase productivity and organizational performance. Similarly,Armstrong (2006) stated that performance management is a methodical process for improving organizational performance by developing the performance of individual and teams. Therefore, the following hypothesis was proposed. 
$\mathbf{H}_{3}: \quad$ Performance Management is positively correlated with business performance.

\subsection{Compensation and Rewards}

According to Hewitt (2009), compensation structure is vital as that provides a platform to pay higher for employees who perform better than the average performing employees which have a motivational effect paving the way to enhancing organizational performance. Moreover, Amit and Belcourt (1999); Arnold (2005); Kwon et al., (2010) indicated the necessity of having a connection with the performance and compensation and that needs to be transparent to the employee and said compensation has to be linked with the goal achievement and new knowledge. Furthermore, Juran and Gryna (1993) defined reward as benefits, like increased salary, bonuses, and promotion, which are conferred for generally superior performance with respect to goals. Similarly, Dee prose (1994) indicates that motivation of employee productivity may lead to providing enhances recognition which paves the way to improve the performance of the organization. Furthermore, Agwu (2013); Armstrong (2006); Kepner (2001); Kirunda (2004) emphasized that reward management as one single factor to determine organizational performance. Thus the following hypothesis was proposed.

$\mathrm{H}_{4}: \quad$ Compensation and Rewards are positively correlated with business performance.

\subsection{Employee Involvement}

Apostolou (2000) states that employee involve organizations encourage employees to get involved in decision- making process without merely indicating to people what is going on. Pater (2001) indicates that 'a high level of employee involvement is vital to the success of any organization'. Moreover, Maltais (2013) indicates that higher employee involvement has multiple benefits for the betterment of the organization whilst keeping employees happy about the importance of contributions made by the employees. Similarly, Denison (1990) concluded that higher levels of employee participation are correlated with organization performance. According to Gryna and Juran (1999), participation is decisive in inspiring action on quality management. Similarly, furthermore, Miller and Monge 
(1986) argued that results of the decisions at the work environment are enriched with the employee inputs whilst enhancing the quality of such decisions that contribute to organizational efficiency. Thus the following hypothesis was proposed.

$\boldsymbol{H}_{5}: \quad$ Employee Involvement is positively correlated with business performance.

\subsection{Top Management Commitment}

The roles of top management out of many other roles are setting quality policies, formulating and deploying of quality goals, providing resources, providing problem- related training, and activating improvement (Juran \& Gryna, 1993). According to Hoffman and Hagerty (1994); Johne and Snelson (1989) in the major areas such as quality management, product development and innovation, a critical role is done by the top management. The world recognized Quality award models namely; "The European Quality Award (1994)" and "the Malcolm Baldrige Quality Award (1999)" include Leadership as one of the most important requirements which provide the path in creating the goals, values, and systems that paved the way to business performance. Moreover, Macinati (2008); Powell (1995) proved that leadership improves overall performance. Thus the following hypothesis was proposed.

$H_{6}: \quad$ Top Management commitment is positively correlated with business performance.

\subsection{Customer Focus}

Customer focus means the extent to which a firm continuously satisfies customer needs and expectations. According to Crosby (1995), the customer is considered in the center of every decision in successful firms. Similarly, Flynn et al., (1994) indicate that throughout the product development cycle the customer involvement helps to minimize any quality problems that can take place once the production is commenced.

Han, Chen, and Ebrahimipour (2007) indicated that customer satisfaction leads to improve a firm's competitiveness in respect of quality, cost, delivery, and flexibility. Similarly, customer satisfaction and operational performance 
are positively related (Han, Chen, \& Ebrahimpour, 2007; Moon et al., 2011).Moreover, Sila and Ebrahimpour (2006) proved a strong connection between customer satisfaction and delivery of quality goods and services and profitability. Thus the following hypothesis was proposed.

H7: $\quad$ Customer Focus is positively correlated with business performance.

\subsection{Process Management}

Anderson et al., (1995) indicated that process management is one of the important elements of integrated quality efforts. Moreover, Anderson et al., (1994); Fynn et al., (1995) indicated that the objective of process management is to reduce the variation by paving the way to incorporate quality into the production process. Moreover, Forza and Flippini (1998) stressed that the achievement of above- mentioned objective makes a situation to reduce costs related to rework and waste whilst increasing the quality of output. Thus, the following hypothesis is proposed.

$H_{8}: \quad$ Process management is positively correlated with business performance.

\subsection{Supplier Quality Management}

A great deal of previous studies proved the positive relation between supplier quality management and operational performance (Ahire \& Shaughnessy, 1998; Phan, Abdallah, \& Matsui, 2011), performance of inventory management, performance of innovation (Phan, Abdallah, \& Matsui, 2011), and performance of overall firm (MacKelprang, Jayaram, \& Xu, 2012; Powel, 1995). Thus the following hypothesis is proposed.

$\boldsymbol{H}_{9}$ : $\quad$ Supplier quality management is positively correlated with business performance.

\subsection{Continual Improvement}

Sollecito and Johnson (2011) indicate continual improvement is an incremental improvement that is linked with the strategic goals and connected with a culture of quality focusing towards process improvement in the overall organization. According to Islam and Mustafa (2008), TQM is a concept that 
provides a framework to continuously improve the organizational processes and systems by changing the management style and by providing value addition to customers on an incremental basis. Deming (1986); Mann (1992) concluded that one of the scientific approach for continuous improvement is the PDCA cycle. Furthermore, the principle shifted the focus for quality from traditional view to a much broader view like a total control of the management system as preached by both Deming and Juran. As a result, Juran (1965) brought the concept of 'prevention not detection' with a final goal of "continuous improvement". Moreover, Flynn, Schroeder, and Sakakibar (1995); Lee, Zuckweiler, and Trimi (2006); Sila (2007) indicated that continual improvement support quality improvements, customer satisfaction, process enhancements and organizational competitiveness. Thus, the following hypothesis is proposed.

$H_{10}$ : Continual Improvement is positively correlated with business performance.

\subsection{Company Size and Company Age (Years of implementation of QMS)}

Terziovski et al., (2003); Lafuente et al., (2010) concluded that company size has no effect on the adoption of ISO 9000 and its impact on business performance. The examination of latest literature on the contingent approach to the TQM-performance relationship, that approach deduces that the outcome of TQM on business results are mediated by both non-controllable environmental factors, according to Chong and Rundus (2004), such as market competitiveness, uncertainty or complexity and also Terziovski and Samson (1999); Hendricks and Singhal (2001a); Brah et al.,( 2002); Taylor and Wright (2003) internal factors, such as how long TQM has been implemented, or the firms' size, or diversification or capital intensity.

However, adequate evidence was not found from the academic literature about the moderating effect of firm size and firm age on the relationship between HRM practices and business performance. Even more, a search through the academic literature reveals insufficient evidence of the moderating effect of firm size and firm age on the relationship between the implementation of Quality Management System and business performance. Thus the following four hypotheses are proposed. 
$\boldsymbol{H}_{11}$ : $\quad$ Size of the firm moderates the relationship between QMS practices and manufacturing Firm's business performance.

$\mathbf{H}_{12}$ : Firm age (Years of implementation of QMS) moderates the relationship between QMS practices and manufacturing Firm's business performance.

H13: Size of the firm moderates the relationship between HRM practices and manufacturing Firm's business performance.

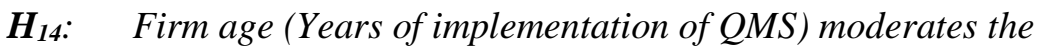
relationship between HRM practices and manufacturing Firm's business performance.

\section{Conclusion}

In Sri Lanka, many manufacturing firms are rushing to be ISO 9000 certified or to implement Quality Management System as per ISO 9000 or TQM, but whether this brings about better business performance is yet to be seen as no such studies have been conducted covering the manufacturing firms of Sri Lanka. However, according to literature, there are many studies done around the world about the impact of ISO 9000 on business performance and also the impact of HRM practices on business performance, but the results are still not the same. In other words, the findings were mixed. To the best of the author's knowledge, no researchers' have empirically examined the relationships between Human Resource Management Practices and the implementation of QMS on business performance in a single model. The study, therefore, seeks to determine how the independent variables influence the dependent variable with the moderating effect of other two variables in manufacturing firms in Sri Lanka.Therefore this study is developed and proposed a research framework for future study to determine the relationships between the constructs. Thus, to determine the relationship between the Impact of HRM practices and the Implementation of QMS on business performance and the moderating effects of firm size and firm age of the Sri Lankan manufacturing firms are proposed.

The research framework in this study has five independent variables which will serve as representatives of the HRM practices and another five independent variables which will serve as representatives of the Quality 
Management System. The Sri Lankan firms' business performance will serve as the dependent variable, while the variables namely firm size and firm age are to serve as the moderating variables for this proposed study. Therefore, this study aimed at filling the highlighted knowledge gaps by examining the Impact of HRM practices and the Implementation of Quality Management practices on business performance of the manufacturing firms in Sri Lanka.In view of that, the examinations of each hypothesis and the subsequent empirical investigations of this study are crucial to validate the proposed research framework. It is expected that the study will be beneficial to local manufacturing firms, policy makers, government and relevant practitioners.

\section{References}

Adams, J. S. (1963). Towards an understanding of inequity. The Journal of Abnormal and Social Psychology, 67(5), 422.

Agwu, M. O. (2013). Impact of fair reward system on employees" job performance in Nigerian Agip Oil Company Limited, Port Harcourt. British Journal of Education, Society and Behavioral Science, 3(1), 47-64.

Ahire, S.L., Golhar, D.Y., Waller, M.A. (1996). Development and validation of TQM implementation constructs. Decision Sciences 27 (1), 23-56.

Ahire, S. L., \& O'shaughnessy, K. C. (1998). The role of top management commitment in quality management: an empirical analysis of the auto parts industry. International Journal of Quality Science, 3(1), 5-37.

Amit, R., \& Belcourt, M. (1999). Human resources management processes: a valuecreating source of competitive advantage. European Management Journal, 17(2), 174-181.

Anderson, S. W., Daly, J. D., \& Johnson, M. F. (1999). Why firms seek ISO 9000 certification: regulatory compliance or competitive advantage? Production and Operations Management, 8(1), 28-43.

Anderson, J.C., Rungtusanatham, M., Schroeder, R.C., \& Devaraja, S. (1995). A path analytic model of a theory of quality management underlying the Deming management method: preliminary empirical findings, Decision Sciences, 26 (5), 637-658.

Antonacopoulou, E. P. (2000). Employee development through self-development in three retail banks. Personnel Review, 29(4), 491-508. 
Anyango, D. M. O., \&Wanjau, K. (2011). Assessment of the relationship between ISO 9001 Certification and Performance of Manufacturing Firms in Nairobi (Unpublished master's thesis). JKUAT, Kenya.

Apostolou, A. (2000). Employee Involvement. Department of Production Engineering and Management Technical. University of Crete.

Armstrong, M. (2006). Human resource management practice. London: Kogan page limited.

Arnold, E. (2005). Managing human resources to improve employee retention. The Health Care Manager, 24(2), 132-140.

Arthur, J. B. (1994). Effects of human resource systems on manufacturing performance and turnover. Academy of Management Journal, 37(3), 670687.

Barney, J. B. (2001). Is the resource-based "view" a useful perspective for strategic management research? Yes. Academy of Management Review, 26(1), 41-56.

Barney, J. B., \& Wright, P. M. (1998). On becoming a strategic partner: The role of human resources in gaining competitive advantage. Human Resource Management (1986-1998), 37(1), 31.

Barney, J. (1991). Firm resources and sustained competitive advantage. Journal of Management, 17(1), 99-120.

Batt, R. (2002). Managing customer services: Human resource practices, quit rates, and sales growth. Academy of Management Journal, 45(3), 587-597.

Becker, S. W. (1993). TQM does work: ten reasons why misguided attempts fail. Management Review, 82(5), 30.

Becker, B., \& Gerhart, B. (1996). The impact of human resource management on organizational performance: Progress and prospects. Academy of Management Journal, 39(4), 779-801.

Bititci, U. S., Carrie, A. S., \& McDevitt, L. (1997). Integrated performance measurement systems: a development guide. International Journal of Operations \& Production Management, 17(5), 522-534.

Boxall, P. (1998). Achieving competitive advantage through human resource strategy: Towards a theory of industry dynamics. Human Resource Management Review, 8(3), 265-288. 
Brah, S. A., Tee, S. S., \& Madhu Rao, B. (2002). Relationship between TQM and performance of Singapore companies. International Journal of Quality \& Reliability Management, 19(4), 356-379.

Champathes, M. R. (2006). Coaching for performance improvement: the "COACH" model. Development and Learning in Organizations: An International Journal, 20(2), 17-18.

Chong, V. K., \& Rundus, M. J. (2004). Total quality management, market competition and organizational performance. The British Accounting Review, 36(2), 155-172.

Chow-Chua, C., Goh, M., \& Boon Wan, T. (2003). Does ISO 9000 certification improve business performance? International Journal of Quality \& Reliability Management, 20(8), 936-953.

Colarelli, S. M., \& Montei, M. S. (1996). Some contextual influences on training utilization. The Journal of Applied Behavioral Science, 32(3), 306-322.

Creswell, J. W. (2017). Qualitative inquiry and research design: Choosing among five approaches. Sage publications.

Crosby, P. B. (1980). Quality is free: The art of making quality certain. Signet.

Curkovic, S., Vickery, S., \& Dröge, C. (2000). Quality-related action programs: their impact on quality performance and firm performance. Decision Sciences, 31(4), 885-902.

Davis, T. R. (1997). Breakdowns in total quality management: an analysis with recommendations. International Journal of Management, 14, 13-22.

Deming, W. E. (1986). Out of the crisis. Massachusetts Institute of Technology. Center for advanced engineering study, Cambridge, MA, 510.

Denison, D. R. (1990). Corporate culture and organizational effectiveness. John Wiley \& Sons.

Deeprose, D. (1994). How to Recognize \& Reward Employees. (p. 11) New York. NY: AMACOM, American Management Association.

El Shenawy, E., Baker, T., \& Lemak, D. J. (2007). A meta-analysis of the effect of TQM on competitive advantage. International Journal of Quality \& Reliability Management, 24(5), 442-471. 
Elwood, P., \& James, A. P. (1996). Productivity gains from the implementation of employee training Programs. Industrial Relations, 33(4), 411-425.

Ericksen, J., \& Dyer, L. (2005). Toward a strategic human resource management model of high reliability organization performance. The International Journal of Human Resource Management, 16(6), 907-928.

Fassoula, E. D. (2006). Transforming the supply chain. Journal of Manufacturing Technology Management, 17(6), 848-860.

Feng, M., Terziovski, M., \& Samson, D. (2007). Relationship of ISO 9001: 2000 quality system certification with operational and business performance: A survey in Australia and New Zealand-based manufacturing and service companies. Journal of Manufacturing Technology Management, 19(1), 2237.

Feigenbaum, A. V. (1985). Quality-Managing the Modern Company. Quality Progress, 18(3), 18-21.

Flynn, B. B., Schroeder, R. G., \& Sakakibara, S. (1994). A framework for quality management research and an associated measurement instrument. Journal of Operations Management, 11(4), 339-366.

Flynn, B. B., Schroeder, R. G., \& Sakakibara, S. (1995). The impact of quality management practices on performance and competitive advantage. Decision Sciences, 26(5), 659-691.

Forza, C., \& Filippini, R. (1998). TQM impact on quality conformance and customer satisfaction: a causal model. International Journal of Production Economics, 55(1), 1-20.

Fotopoulos, C. B., \& Psomas, E. L. (2009). The impact of "soft" and "hard" TQM elements on quality management results. International Journal of Quality \& Reliability Management, 26(2), 150-163.

Fotopoulos, C. V., Kafetzopoulos, D. P., \& Psomas, E. L. (2009). Assessing the critical factors and their impact on the effective implementation of a food safety management system. International Journal of Quality \& Reliability Management, 26(9), 894-910.

Gadenne, D., \& Sharma, B. (2009). An investigation of the hard and soft quality management factors of Australian SMEs and their association with firm performance. International Journal of Quality \& Reliability Management, 26(9), 865-880. 
Gamage, A. S. (2014). Recruitment and selection practices in manufacturing SMEs in Japan: An analysis of the link with business performance. Ruhuna Journal of Management and Finance, 1(1), 37-52.

Gryna, F. M., \& Juran, J. M. (1999). Quality and costs. New York: McGraw-Hill.

Guthrie, J. P., \& Hollensbe, E. C. (2004). Group incentives and performance: A study of spontaneous goal setting, goal choice and commitment. Journal of Management, 30(2), 263-284.

Han, S. B., Chen, S. K., \& Ebrahimpour, M. (2007). The impact of ISO 9000 on TQM and business performance. The Journal of Business and Economic Studies, 13(2), 1.

Hayton, J. C. (2003). Strategic human capital management in SMEs: An empirical study of entrepreneurial performance. Human Resource Management, 42(4), 375-391.

Hendricks, K. B., \& Singhal, V. R. (2001). Firm characteristics, total quality management, and financial performance. Journal of Operations Management, 19(3), 269-285.

Heras, I., Dick, G. P., \& Casadesus, M. (2002). ISO 9000 registration's impact on sales and profitability: a longitudinal analysis of performance before and after accreditation. International Journal of Quality \& Reliability Management, 19(6), 774-791.

Hewitt, A. (2009). Managing performance with incentive pay. Journal of Personnel Management. 7 (1), 20-31.

Huffman, R. C., \& Hegarty, W. H. (1993). Top management influence on innovations: Effects of executive characteristics and social culture. Journal of management, 19(3), 549-574.

Huselid, M. A. (1995). The impact of human resource management practices on turnover, productivity, and corporate financial performance. Academy of Management Journal, 38(3), 635-672.

Ichniowski, C., \& Shaw, K. (1999). The effects of human resource management systems on economic performance: An international comparison of US and Japanese plants. Management Science, 45(5), 704-721. 
Ichniowski, C., Shaw, K., \& Prennushi, G. (1997). The effects of human resource management practices on productivity: A study of steel finishing lines. The American Economic Review, 291-313.

Islam, R., \& Mustapha, M. R. (2010). Organizational approach to total quality management: a case study. Asian Journal of Business and Accounting, 1(2).

Ismyrlis, V., \& Moschidis, O. (2015). The use of quality management systems, tools, and techniques in ISO 9001: 2008 certified companies with multidimensional statistics: the Greek case. Total Quality Management \& Business Excellence, 26(5-6), 497-514.

Johne, F. A., \& Snelson, P. A. (1989). Product development approaches in established firms. Industrial Marketing Management, 18(2), 113-124.

Judge, T. A., Scott, B. A., \& Ilies, R. (2006). Hostility, job attitudes, and workplace deviance: test of a multilevel model. Journal of Applied Psychology, 91(1), 126.

Juran J.M. (1965). Managerial Breakthrough. New York: McGraw- Hill.

Juran, J. M. (1998). Quality in Supplier Relations. New York: McGraw- Hill Professional.

Juran, J. M., \& Gryna, F. M. (1993). Quality planning and analysis. (3rd Ed.) New York: McGraw-Hill.

Khan, M. A. (2010). Effects of human resource management practices on organizational performance-an empirical study of oil and gas industry in Pakistan. European Journal of Economics, Finance and Administrative Sciences, 24(157-174), 6.

Katou, A. A., \& Budhwar, P. S. (2006). Human resource management systems and organizational performance: a test of a mediating model in the Greek manufacturing context. The International Journal of Human Resource Management, 17(7), 1223-1253.

Kepner, K. W. (2001). Human Resource Management in Agribusiness. University of Florida, Gainesville, FL., $p$-90.

Kirunda, H. K. (2004). Performance-based rewards and the performance of teachers in private secondary schools in Kampala District. Unpublished Masters Dissertation, Kampala. 
Klefsjo, B., Bergquist, B., \& Edgeman, R. L. (2006). Six Sigma and Total Quality Management: different day, same soup? International Journal of Six Sigma and Competitive Advantage, 2(2), 162-178.

Kuntze, R., \& Matulich, E. (2010). Google: Searching for value. Journal of Case Research in Business and Economics, 2, 1.

Kwon, K., Bae, J., \& Lawler, J. J. (2010). High commitment HR practices and top performers. Management International Review, 50(1), 57-80.

Lafuente, E., Bayo-Moriones, A., \& García-Cestona, M. (2010). ISO-9000 Certification and Ownership Structure: Effects upon Firm Performance. British Journal of Management, 21(3), 649-665.

Lee, S. M., Zuckweiler, K. M., \& Trimi, S. (2006). Modernization of the Malcolm Baldrige national quality award. International Journal of Production Research, 44(23), 5089-5106.

Louise, C. (1996). Analysing business performance: counting the "soft" issues. Leadership \& Organization Development Journal, 17(4), 21-28.

MacDuffie, J. P. (1995). Human resource bundles and manufacturing performance: Organizational logic and flexible production systems in the world auto industry. ILR Review, 48(2), 197-221.

Macinati, M. S. (2008). The relationship between quality management systems and organizational performance in the Italian National Health Service. Health Policy, 85(2), 228-241.

Mackelprang, A. W., Jayaram, J., \& Xu, K. (2012). The influence of types of training on service system performance in mass service and service shop operations. International Journal of Production Economics, 138(1), 183194.

Madu, C. N., Aheto, J., Kuei, C. H., \& Winokur, D. (1996). Adoption of strategic total quality management philosophies Multi-criteria decision analysis model. International Journal of Quality \& Reliability Management, 13(3), 57-72.

Maltais, D (2013). Employee Engagement? The New Focus Should be Employee Involvement, www.tlnt.com/2013/02/12/employee-engagement-the-newfocusshould-be-employeeinvolvement/http://www.tlnt.com/2013/02/12/employeeengagement-thenew-focus-should-be-employee-involvement/, Accessed on 10 May 2015 
Mann, R. S. (1992). The development of a framework to assist in the implementation of Total Quality Management (TQM) (Doctoral dissertation, University of Liverpool).

Manente, M. (2008). Babylon and Ontology: Multilingual and cognitive e-learning management system via PDA phone. Education, Audiovisual and Culture Executive Agency (EACEA), Brussels.

Miller, K. I., \& Monge, P. R. (1986). Participation, satisfaction, and productivity: A meta-analytic review. Academy of Management Journal, 29(4), 727-753.

Moon, J. Y., Lee, S. C., Yong-Seung, P., \& Suh, Y. H. (2011). A study on the causal relationships in the Korean National Quality Award model. Total Quality Management \& Business Excellence, 22(7), 705-726.

Mudrack, P. E. (1993). An investigation into the acceptability of workplace behaviors of a dubious ethical nature. Journal of Business Ethics, 12(7), 517524.

Nayab, N. (2011). Evolution of Human Resource Management: The Personnel Management Phase. Brighthub Project Management, 19.

Nzuve, S. N. M. (2007). Management of Human Resources, an Indian perspective.

Okpara, J. O., \& Wynn, P. (2007). Human resource management practices in a transition economy: Challenges and prospects. Management Research News, 31(1), 57-76.

Oyer, P. (2004). Why do firms use incentives that have no incentive effects? The Journal of Finance, 59(4), 1619-1650.

Pater, R. (2001). The secrets of involvement, part II. Occupational Health \& Safety, 70(1), 26-26.

Pfeffer, J. (1994). Competitive advantage through people: Unleashing the power of the work force. Harvard Business Press.

Pfeifer, T. (1994). Manufacturing excellence: the competitive edge. Kluwer Academic Publishers.

Pfeffer, J. (1995). Producing sustainable competitive advantage through the effective management of people. The Academy of Management Executive, 9(1), 55-69. 
Phan, A. C., Abdallah, A. B., \& Matsui, Y. (2011). Quality management practices and competitive performance: Empirical evidence from Japanese manufacturing companies. International Journal of Production Economics, 133(2), 518-529.

Powell, T. C. (1995). Total quality management as competitive advantage: a review and empirical study. Strategic Management Journal, 16(1), 15-37.

Power, D., \& Sohal, A. S. (2000). An empirical study of human resource management strategies and practices in Australian just-in-time environments. International Journal of Operations \& Production Management, 20(8), 932-958.

Quazi, H. A., Hong, C. W., \& Meng, C. T. (2002). Impact of ISO 9000 certification on quality management practices: A comparative study. Total quality management, 13(1), 53-67.

Quinn, R. E., \& Rohrbaugh, J. (1983). A spatial model of effectiveness criteria: Towards a competing values approach to organizational analysis. Management Science, 29(3), 363-377.

Rahman, S. U., \& Bullock, P. (2005). Soft TQM, hard TQM, and organisational performance relationships: an empirical investigation. Omega, 33(1), 73-83.

Rajan, R. G., \& Wulf, J. (2006). Are perks purely managerial excess? Journal of Financial Economics, 79(1), 1-33.

Rajan, R, \&Wulf, J. (2006). Are perks purely managerial excess? Journal of Financial Economics, 79(1), 1-33. doi.org/10.10 16/j.jfineco.2005.01.003

Rosen, S. (2000). Does the Composition of Pay Matter? Employee benefits and labor markets in Canada and the United States, 13-30.

Sels, L., De Winne, S., Delmotte, J., Maes, J., Faems, D., \& Forrier, A. (2006). Linking HRM and small business performance: an examination of the impact of HRM intensity on the productivity and financial performance of small businesses. Small Business Economics, 26(1), 83-101.

Schwab, K. (2016). The global competitiveness report 2016-2017, Ed. In WE Forum.

Sharma, B., \&Gadenne, D. (2002). An inter-industry comparison of quality management practices and performance. Managing Service Quality: An International Journal, 12(6), 394-404. 
Sila, I. (2007). Examining the effects of contextual factors on TQM and performance through the lens of organizational theories: An empirical study. Journal of Operations Management, 25(1), 83-109.

Sila, I., \&Ebrahimpour, M. (2005). Critical linkages among TQM factors and business results. International Journal of Operations \& Production Management, 25(11), 1123-1155.

Sila, L. Ebrahimpour, M. et al (2006). "Quality in supply chains: an empirical analysis", Supply chain management: An International Journal, 11(6), 491502.

Sollecito, W. A., \& Johnson, J. K. (2011). McLaughlin and Kaluzny's continuous quality improvement in health care. Jones \& Bartlett Publishers.

Sparrow, W. A., Bradshaw, E. J., Lamoureux, E., \& Tirosh, O. (2002). Ageing effects on the attention demands of walking. Human Movement Science, 21(5), 961-972.

Sun, H. (2000). Total quality management, ISO 9000 certification and performance improvement. International Journal of Quality \& Reliability Management, 17(2), 168-179.

Tari, J. J., Molina, J. F., \& Castejon, J. L. (2007). The relationship between quality management practices and their effects on quality outcomes. European Journal of Operational Research, 183(2), 483-501.

Taylor, W. A. (1997). Leadership challenges for smaller organisations: Selfperceptions of TQM implementation. Omega, 25(5), 567-579.

Taylor, W. A., \& Wright, G. H. (2003). A longitudinal study of TQM implementation: factors influencing success and failure. Omega, 31(2), 97111.

Teixeira, A. (2002). On the link between human capital and firm performance. A theoretical and.

Terziovski, M., \& Samson, D. (1999). The link between total quality management practice and organisational performance. International Journal of Quality \& Reliability Management, 16(3), 226-237.

Terziovski, M., Samson, D., \& Dow, D. (1997). The business value of quality management systems certification. Evidence from Australia and New Zealand. Journal of Operations Management, 15(1), 1-18. 
Terziovski, M., Power, D., \&Sohal, A. S. (2003). The longitudinal effects of the ISO 9000 certification process on business performance. European Journal of Operational Research, 146(3), 580-595.

Tessema, M. and Soeters, J. (2006). Challenges and prospects of HRM in developing countries: testing the HRM-performance link in Eritrean civil service, International Journal of Human Resource Management, 17(1), 86105.

Tranfield, D., Denyer, D., \& Smart, P. (2003). Towards a methodology for developing evidence-informed management knowledge by means of systematic review. British Journal of Management, 14(3), 207-222.

Uysal, G., \&Koca, G. (2009). HR and firm performance at companies in Turkey: Correlative analysis. Journal of Modern Accounting and Auditing, 5(1), 45

Venkatraman, N., \& Ramanujam, V. (1986). Measurement of business performance in strategy research: A comparison of approaches. Academy of Management Review, 11(4), 801-814.

Wall, T. D., \& Wood, S. J. (2005). The romance of human resource management and business performance, and the case for big science. Human Relations, 58(4), 429-462.

Walker, J.W. (2001). Perspectives of Human Resource Planning. Boston: Harvard University Press.

Wambugu, M. G. (2010). Effects of quality management practices on employee efficiency. MBA Thesis, University of Nairobi.

Way, S. A. (2002). High performance work systems and intermediate indicators of firm performance within the US small business sector. Journal of Management, 28(6), 765-785.

Westphal, J. D., Gulati, R., \& Shortell, S. M. (1996, August). The Institutionalization of Total Quality Management: The Emergence of Normative Tqm Adoption and the Consequences for Organizational Legitimacy and Performance. Academy of Management Proceedings (Vol. 1996, No. 1, pp. 249-253).

White, A. M. (1999). The relationship between ISO9000 and business performance: Does Registration really matter? Journal of Managerial Issues, XI, 330-343. 
Withers, B., \& Ebrahimpour, M. (2000). Does ISO 9000 certification affect the dimensions of quality used for competitive advantage? European Management Journal, 18(4), 431-443.

Wright, M., Filatotchev, I., Hoskisson, R. E., \& Peng, M. W. (2005). Strategy research in emerging economies: Challenging the conventional wisdom. Journal of Management Studies, 42(1), 1-33. 